\title{
The Mechanism of Muscarinic Agonist-Stimulated Inositol Phosphate Formation in Permeabilized Ileal Smooth Muscle
}

\author{
Kenji Honda, Yukio Takano and Hiro-o Kamiya \\ Department of Pharmacology, Faculty of Pharmaceutical Sciences, Fukuoka University, Fukuoka 814-01, Japan
}

Received February 24, 1994 Accepted April 18, 1994

\begin{abstract}
Muscarinic agonists and guanylyl-5'-imidodiphosphate ( $\mathrm{Gpp}(\mathrm{NH}) \mathrm{p})$ stimulated formation of inositol phosphates in permeabilized longitudinal smooth muscle of guinea pig ileum. Gpp(NH)p markedly potentiated the formation of inositol bisphosphate $\left(\mathrm{IP}_{2}\right)$ and inositol trisphosphate $\left(\mathrm{IP}_{3}\right)$ stimulated by carbachol, but increased inositol monophosphate formation (IP $\left.{ }_{1}\right)$ only slightly. Gpp(NH)p enhanced the formation of $\mathrm{IP}_{2}+\mathrm{IP}_{3}$ induced by either acetylcholine or carbachol about fourfold in a synergistic manner, but enhanced the effects of oxotremorine and pilocarpine less than twofold in an additive manner. Elevation of $\mathrm{Ca}^{2+}$ concentration resulted in increases of the inositol phosphate levels stimulated by both carbachol and $\mathrm{Gpp}(\mathrm{NH}) \mathrm{p}$. The optimal concentration of $\mathrm{Ca}^{2+}$ for carbachol-stimulated formations of $\mathrm{IP}_{2}+\mathrm{IP}_{3}$ was shifted to a lower $\mathrm{Ca}^{2+}$ concentration in the presence of $\mathrm{Gpp}(\mathrm{NH}) \mathrm{p}$. These findings suggest that muscarinic receptor-stimulated polyphosphoinositide hydrolysis in ileal smooth muscle results in inositol polyphosphate formation via GTP binding protein (G-protein). The muscarinic receptor-activated G-protein decreases the $\mathrm{Ca}^{2+}$ requirement of polyphosphoinositide hydrolysis. Muscarinic agonists stimulate inositol polyphosphate formation by interaction of the $\mathrm{G}$-protein activation of a phosphoinositide specific phospholipase $\mathrm{C}$ with $\mathrm{Ca}^{2+}$ influx.
\end{abstract}

Keywords: Muscarinic agonist, Phosphoinositide response, Full agonist, G-protein, Ileum

Activation of the muscarinic receptor (mACh $\mathrm{R}$ ) causes a variety of cellular responses, including inhibition of adenylate cyclase, activation of phospholipase $\mathrm{C}$ (PLC) and activation of $\mathrm{K}^{+}$ion channels $(1-4)$. The mACh Rmediated responses are known to occur by the interaction of receptors with GTP binding proteins (G-protein) in the membranes (5-9). Muscarinic agonists have been classified into two types, designated as full agonists and partial agonists, based on differences in the efficacy of inositol phosphate formation and adenylate cyclase inhibition. Fisher (10) suggested that the difference in the efficacies of agonists arises from conformational restraints imposed by the coupling state of the receptor and agonist. Several studies have demonstrated that various types of muscarinic agonists stimulate intracellular second messengers that cause contractile responses in longitudinal smooth muscle of guinea pig ileum $(11,12)$. We have reported that the M3 subtype of mACh $\mathbf{R}$ is associated with phosphoinositide hydrolysis in guinea pig ileum (13). In the smooth muscle of guinea pig ileum, however, it is unclear how the interaction of muscarinic agonist-receptor results in the difference of efficacy in inositol phos- phate formation.

In the present study, we examined inositol phosphate formation mediated by different types of muscarinic agonists in the presence of unhydrolyzable GTP analogs, $\mathrm{Gpp}(\mathrm{NH}) \mathrm{p}$, using permeabilized ileal smooth muscle, and we discussed the difference in the abilities of muscarinic agonists.

\section{MATERIALS AND METHODS}

\section{Materials}

Myo-(2-) ${ }^{3} \mathrm{H}$-inositol (specific activity, $703 \mathrm{GBq} / \mathrm{mmol}$ ) was obtained from Amersham (Buckinghamshire, UK). Pertussis toxin (PTX) and cholera toxin (CTX) were gifts from the Chemo-Sero-Therapeutic Research Institute (Kumamoto). The following reagents were obtained from the indicated commercial sources: ethylene glycol bis ( $\beta$-amino-ethylether)- $N, N, N^{\prime}, N^{\prime}$-tetra acetic acid (EGTA; Dojindo Laboratories, Kumamoto); pilocarpine hydrochloride (Wako Pure Chemical Industries, Osaka); guanyl-5'-yl-imidodiphosphate (Gpp(NH)p) (Boehringer Mannheim, Mannheim, Germany); digitonin and carbachol 
(Merck, Darmstadt, Germany); oxotremorine sesquifumarate and eserine (Sigma, St. Louis, MO, USA); acetylcholine chloride (Nacalai Tesque, Kyoto); and Dowex-1 (AG-1, 100-200 mesh, $\times 8$ in the formate form; Bio-Rad, Hercules, CA, USA).

\section{Labelling with ${ }^{3} \mathrm{H}$-inositol in ileal smooth muscle}

Male Hartley guinea pigs (300-450 g), obtained from Kyudo (Kumamoto), were housed in a room at $20-25^{\circ} \mathrm{C}$ with a 12-hr light-dark cycle (light on from 7:00 a.m.). Guinea pigs were decapitated, and their ileum was promptly removed and placed in oxygenated KrebsRinger bicarbonate buffer (KRB) of the following composition: $123 \mathrm{mM} \mathrm{NaCl}, 5.0 \mathrm{mM} \mathrm{KCl}, 1.3 \mathrm{mM} \mathrm{MgCl}_{2}, 1.4$ $\mathrm{mM} \mathrm{K \textrm {KH } _ { 2 } \mathrm { PO } _ { 4 } , 2 6 . 0 \mathrm { mM } \mathrm { NaHCO }}, 0.8 \mathrm{mM} \mathrm{CaCl}_{2}$ and $10.0 \mathrm{mM}$ glucose, $\mathrm{pH} 7.4$.

Experiments on ${ }^{3} \mathrm{H}$-inositol phosphate formation were performed as described previously (13). Briefly, the longitudinal muscle layer was cut into 20 pieces of approximately $10-\mathrm{mm}$ length, which were preincubated for $10-$ min in $\mathrm{KRB}$ at $37^{\circ} \mathrm{C}$ under $5 \% \mathrm{CO}_{2}-95 \% \mathrm{O}_{2}$. Then the pieces were prelabeled with $10 \mu \mathrm{Ci}(370 \mathrm{kBq}) / \mathrm{ml}$ of myo- ${ }^{3} \mathrm{H}-$ inositol for $3 \mathrm{hr}$ at $37^{\circ} \mathrm{C}$. The labelled strips were washed with $\mathrm{KRB}$ to remove excess myo- ${ }^{3} \mathrm{H}$-inositol and then weighed.

\section{Formation of ${ }^{3} H$-inositol phosphates in permeabilized longitudinal muscles.}

Longitudinal muscles, ${ }^{3} \mathrm{H}$-labelled muscles, were preincubated in KRB for $10 \mathrm{~min}$ at $37^{\circ} \mathrm{C}$ and then permeabilized with the non-ionic detergent digitonin $(20 \mu \mathrm{M})$ for $10 \mathrm{~min}$ at $37^{\circ} \mathrm{C}$ in $\mathrm{Ca}^{2+}$-free $\mathrm{Li}-\mathrm{KRB}, \mathrm{pH} 7.4$ containing $10 \mathrm{mM}$ EGTA, in which $\mathrm{NaCl}$ was replaced by $10 \mathrm{mM}$ $\mathrm{LiCl}(\mathrm{Li}-\mathrm{KRB})$. After the permeabilized strips were washed three times in $\mathrm{Ca}^{2+}$-free $\mathrm{Li}-\mathrm{KRB}$, they were transferred to plastic tubes and incubated with muscarinic agonists and Gpp(NH)p in $500 \mu 1$ of oxygenated Li-KRB for $10 \mathrm{~min}$ at $37^{\circ} \mathrm{C}$. Reactions were terminated by adding of $2 \mathrm{ml}$ of ice-cold chloroform/methanol $(1: 2$ by v/v).

The reaction mixtures were then homogenized in a glass homogenizer, and the homogenates were mixed with equal volumes of water and chloroform and centrifuged at $1,000 \times \mathrm{g}$ for $10 \mathrm{~min}$. The upper aqueous phase was applied to a AG1-X8 column (100-200 mesh, formate form, $50 \% \mathrm{w} / \mathrm{v}$ slurry), and ${ }^{3} \mathrm{H}$-inositol phosphates were separated into ${ }^{3} \mathrm{H}$-inositol monophosphate $\left({ }^{3} \mathrm{H}-\mathrm{IP}{ }_{1}\right),{ }^{3} \mathrm{H}$ inositol bisphosphate $\left({ }^{3} \mathrm{H}-\mathrm{IP}_{2}\right)$ and ${ }^{3} \mathrm{H}$-inositol trisphosphate $\left({ }^{3} \mathrm{H}-\mathrm{IP}_{3}\right)$ by a stepwise gradient elution with ammonium formate/formic acid buffers as described by Berridge et al. (14). The radioactivity content of each fraction was counted in a liquid scintillation spectrometer (LKB1217, RACK $\beta$ ETA).

Cell damage induced by $20 \mu \mathrm{M}$ digitonin treatment was examined by electron-microscopy. Ileal smooth muscle appeared to be morphologically intact after treatment with digitonin (data not shown).
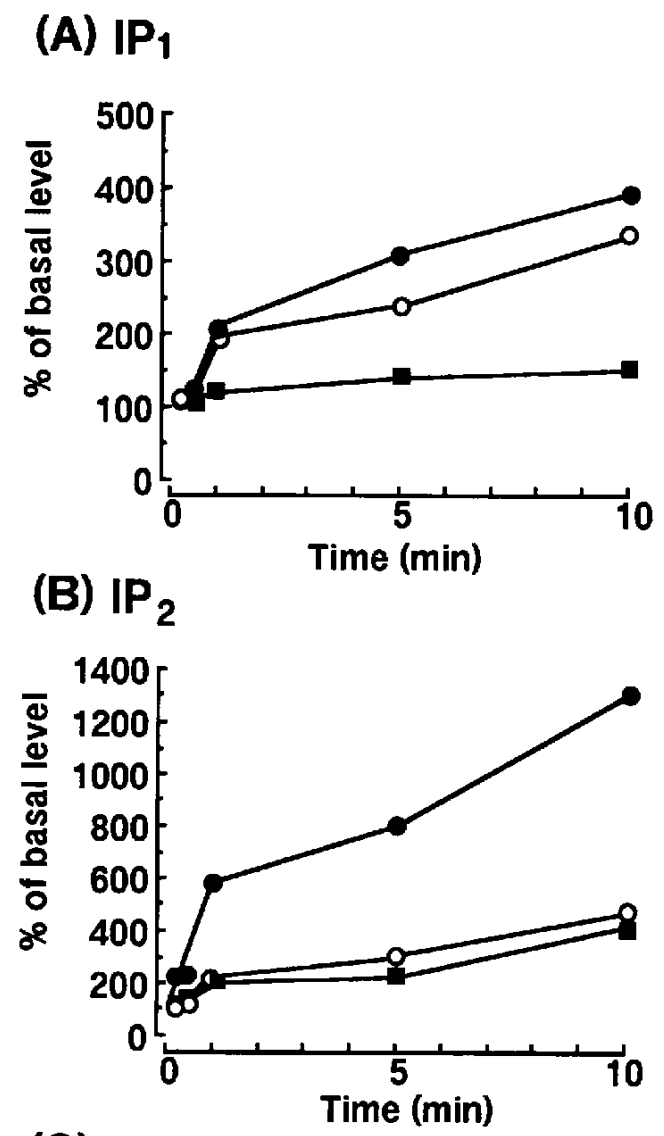

(C) $\mathrm{IP}_{3}$

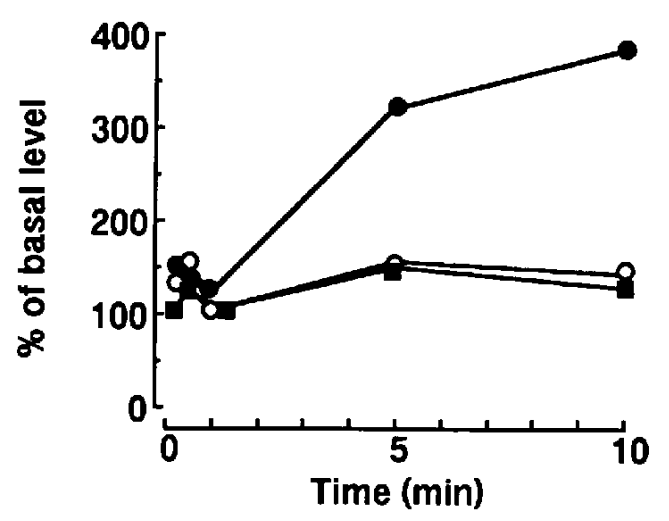

Fig. 1. Time courses of carbachol $(100 \mu \mathrm{M})$ - and $\mathrm{Gpp}(\mathrm{NH}) \mathrm{p}(300$ $\mu \mathrm{M})$-stimulated inositol phosphate formation in permeabilized ileal smooth muscle. Increases of $\mathrm{IP}_{1}(\mathrm{~A}), \mathrm{IP}_{2}(\mathrm{~B})$ and $\mathrm{IP}_{3}(\mathrm{C})$ are expressed as percentages of basal levels. The basal radioactivities ( $\mathrm{dpm} / \mathrm{mg}$ wet weight) recovered in inositol phosphates were $141 \pm 23.3 \mathrm{dpm}\left(\mathrm{IP}_{1}\right)$, $25.9 \pm 1.7 \mathrm{dpm}\left(\mathrm{IP}_{2}\right)$ and $18.7 \pm 2.7 \mathrm{dpm}\left(\mathrm{IP}_{3}\right)$ after $10 \mathrm{~min}$. Values are means for 3 to 4 experiments. : carbachol $+\mathrm{Gpp}(\mathrm{NH}) \mathrm{p}$, O: carbachol, a: Gpp(NH)p. 


\section{RESULTS}

Time courses for $I P_{1}, I P_{2}$ and $I P_{3}$ formation in permeabilized ileal muscles

Figure 1 shows the time course for formations of $\mathrm{IP}_{1}$, $\mathrm{IP}_{2}$ and $\mathrm{IP}_{3}$ stimulated by carbachol $(100 \mu \mathrm{M})$ and $\mathrm{Gpp}(\mathrm{NH}) \mathrm{p}(300 \mu \mathrm{M})$. The muscarinic agonist carbachol stimulated rapid formations of $\mathrm{IP}_{1}, \mathrm{IP}_{2}$ and $\mathrm{IP}_{3}$ within 60 $\mathrm{sec}$, and their levels persisted for at least $10 \mathrm{~min}$. The carbachol-stimulated $\mathrm{IP}_{2}$ formation in the first $60 \mathrm{sec}$ was markedly enhanced in the presence of $\mathrm{Gpp}(\mathrm{NH}) \mathrm{p}$.

\section{(A) IP1}
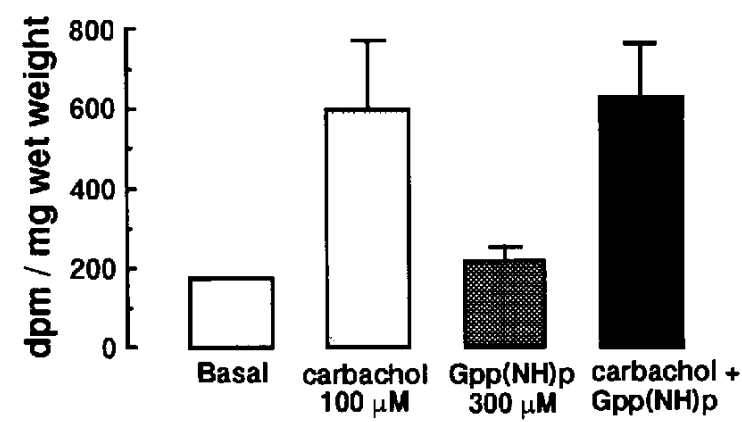

\section{(B) $\mathrm{IP}_{2}$}
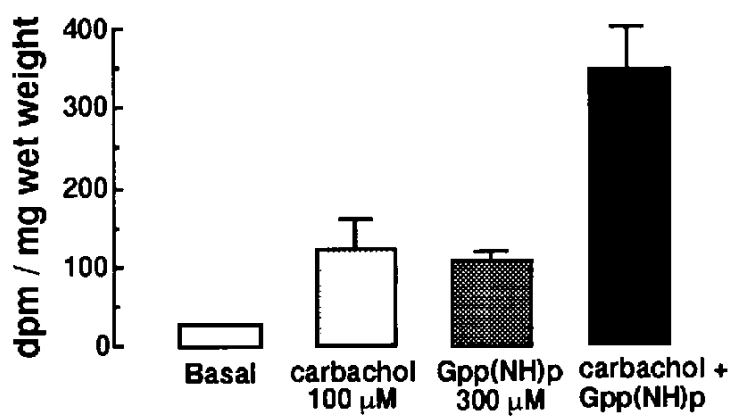

\section{(C) $\mathrm{IP}_{3}$}
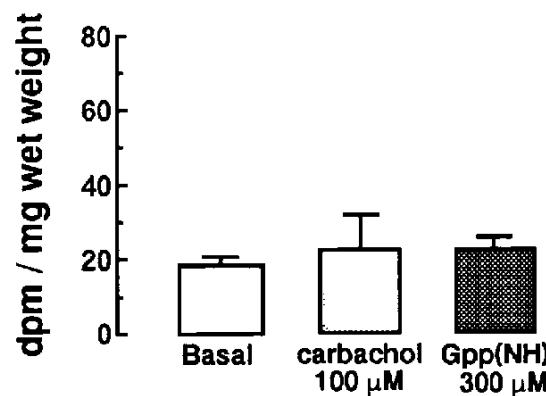

Gpp(NH)p carbachol + $300 \mu M \operatorname{Gpp}(\mathbf{N H}) p$

Fig. 2. Combined effects of carbachol $(100 \ell \mathrm{M})$ and $\mathrm{Gpp}(\mathrm{NH}) \mathrm{p}$ $(300 \mu \mathrm{M})$ on formations of inositol phosphates in permeabilized ileal smooth muscle. Values are expressed as radioactivities ( $\mathrm{dpm} / \mathrm{mg}$ wet weight) and are means \pm S.E. for 4 to 6 experiments.
Effects of $G p p(N H) p$ on muscarinic agonists-stimulated formation of inositol phosphates

Ileal smooth muscles were treated with the non-ionic detergent digitonin to make them permeable to GTP analogues. In permeabilized ileal smooth muscle, the stable analogue of GTP, Gpp(NH)p $(300 \mu \mathrm{M})$, markedly potentiated the formations of $\mathrm{IP}_{2}$ and $\mathrm{IP}_{3}$ induced by carbachol $(100 \mu \mathrm{M})$, but had little effect on $\mathrm{IP}_{1}$ formation stimulated by carbachol (Figs. 1 and 2). $\mathrm{IP}_{2}$ is formed from $\mathrm{IP}_{3}$ and is also formed from PIP by activation of PLC. Therefore, there is no single substrate for $\mathbf{I P}_{2}$ formation in this tissue; and so in this study, we determined the formation of $\mathrm{IP}_{2}+\mathrm{IP}_{3}$ as inositol polyphosphate formation. $\mathrm{Gpp}(\mathrm{NH}) \mathrm{p}$ potentiated the formation of $\mathrm{IP}_{2}+\mathrm{IP}_{3}$ dosedependently (Fig. 3).

Next, we examined the effect of $\mathrm{Gpp}(\mathrm{NH}) \mathrm{p}$ on the formation of $\mathrm{IP}_{2}+\mathrm{IP}_{3}$ stimulated by various muscarinic

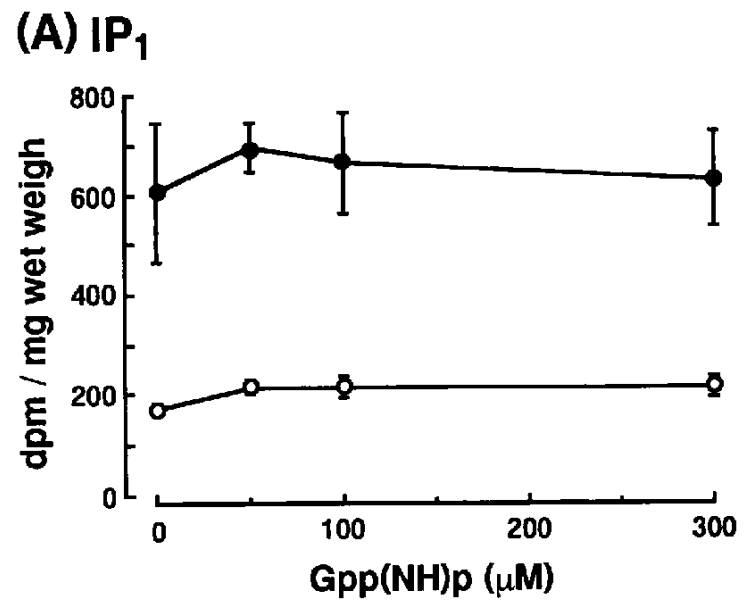

\section{(B) $I P_{2}+I P_{3}$}

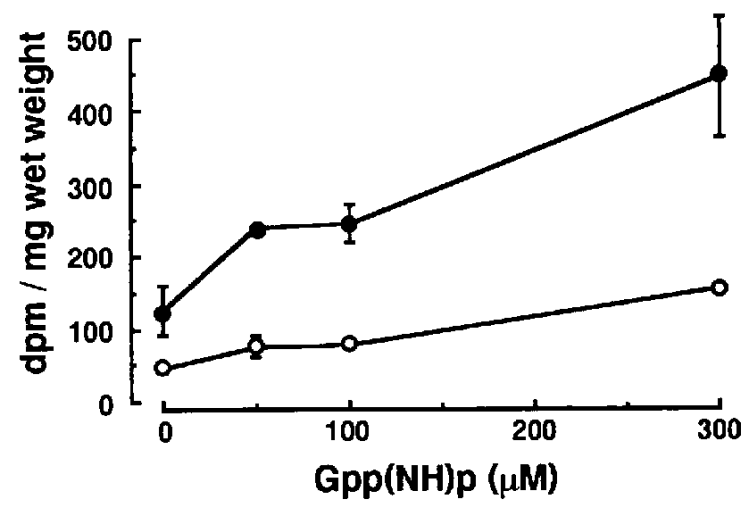

Fig. 3. Concentration-response relationship of the potentiation of $100 \mu \mathrm{M}$ carbachol-stimulated formations of inositol phosphates by Gpp(NH)p in permeabilized ileal smooth muscle. The responses were measured in combination with increasing concentrations of $\mathrm{Gpp}(\mathrm{NH}) \mathrm{p}$. Values are expressed as radioactivities $(\mathrm{dpm} / \mathrm{mg}$ wet weight) and are means \pm S.E. for 4 to 6 experiments. $\bigcirc$ : control, : carbacol. 


\section{(A) $\mathrm{IP}_{\mathbf{1}}$}
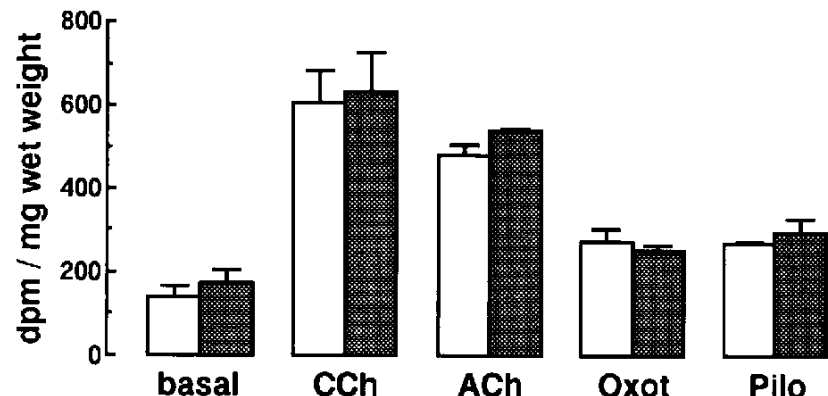

\section{(B) $I P_{2}+I P_{3}$}
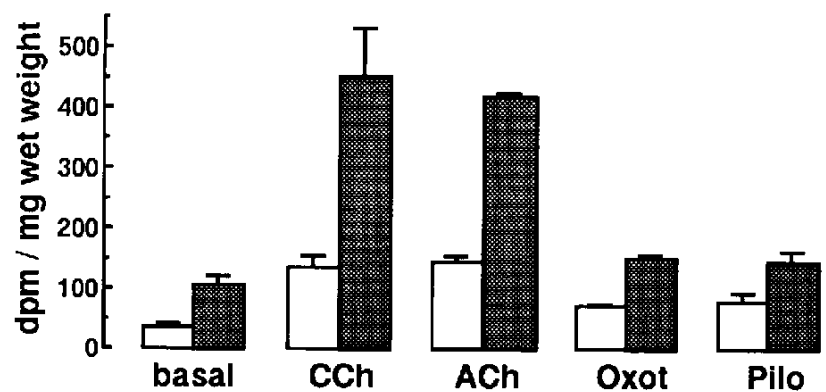

Fig. 4. Comparison of potentiations by Gpp(NH)p $(300 \mu \mathrm{M})$ of the stimulation of inositol phosphate formation by various muscarinic agonists $(100 \mu \mathrm{M})$ in permeabilized ileal smooth muscle. Acetylcholine was tested with $1 \mu \mathrm{M}$ eserine to minimize its hydrolysis. Values are expressed as radioactivities $(\mathrm{dpm} / \mathrm{mg}$ wet weight) and are means \pm S.E. for 4 to 12 experiments. CCh: carbachol, ACh: acetylcholine, Oxot: oxotremorine, Pilo: pilocarpine. ᄃ: control, Gpp(NH)p.

agonists. $\mathrm{Gpp}(\mathrm{NH}) \mathrm{p}$ enhanced the formation of $\mathrm{IP}_{2}+$ $\mathrm{IP}_{3}$ induced by either acetylcholine or carbachol about fourfold in a synergistic manner, but enhanced the effects of oxtremorine and pilocarpine less than twofold in an additive manner (Fig. 4).

\section{Effects of $\mathrm{Ca}^{2+}$ on formation of inositol phosphates in permeabilized ileal smooth muscle}

The requirement of $\mathrm{Ca}^{2+}$ for formation of inositol phosphates in permealized ileal smooth muscle is shown in Fig. 5. Elevation of $\mathrm{Ca}^{21}$ resulted in increases in the level of inositol phosphates stimulated by carbachol and $\mathrm{Gpp}(\mathrm{NH}) \mathrm{p}$. The carbachol-stimulated formation of $\mathrm{IP}_{2}$ $+\mathrm{IP}_{3}$ was greatly potentiated by $\mathrm{Gpp}(\mathrm{NH}) \mathrm{p}$ in the presence of $0.09 \mathrm{mM} \mathrm{Ca}^{2+}$. Interestingly, the optimal concentration of $\mathrm{Ca}^{2+}(0.18 \mathrm{mM})$ for carbachol-stimulated formation of $\mathrm{IP}_{2}+\mathrm{IP}_{3}$ was decreased to $0.09 \mathrm{mM}$ in the presence of $\mathrm{Gpp}(\mathrm{NH}) \mathrm{p}$. However, the optimal concentration of $\mathrm{Ca}^{2+}$ for IP formation stimulated by carbachol was not affected by $\mathrm{Gpp}(\mathrm{NH}) \mathrm{p}$.

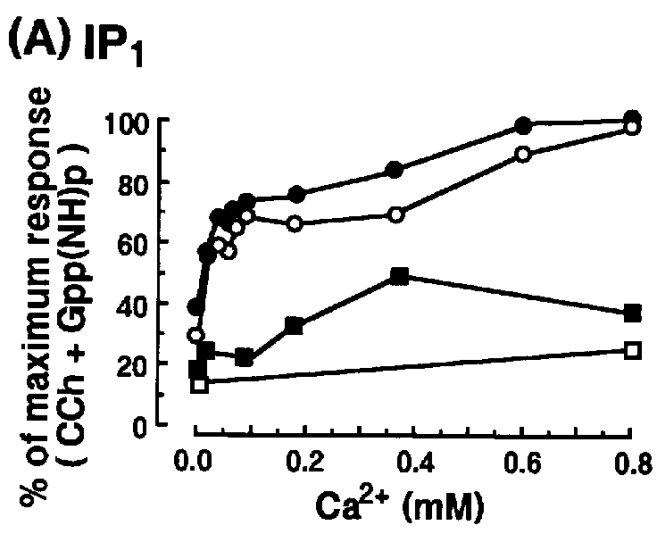

(B) $I P_{2}+I P_{3}$

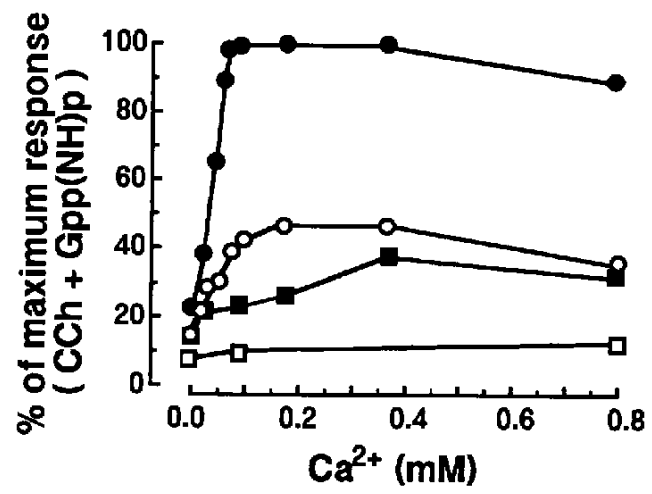

Fig. 5. Effects of $\mathrm{Ca}^{2+}$ on formations of inositol phosphates in permeabilized ileal smooth muscle. Values are expressed as percentages of the maximal response of $\mathrm{IP}_{1}(\mathrm{~A})$ or $\mathrm{IP}_{2}+\mathrm{IP}_{3}(\mathrm{~B})$ stimulated by a combination of carbachol $(100 \mu \mathrm{M})$ and $\mathrm{Gpp}(\mathrm{NH}) \mathrm{p}(300 \mu \mathrm{M})$ and are means for 3 to 5 experiments. $\square$ : basal, $\square$ : $G p p(N H) p$, : carbachol, : carbachol $+\mathrm{Gpp}(\mathrm{NH}) \mathrm{p}$.

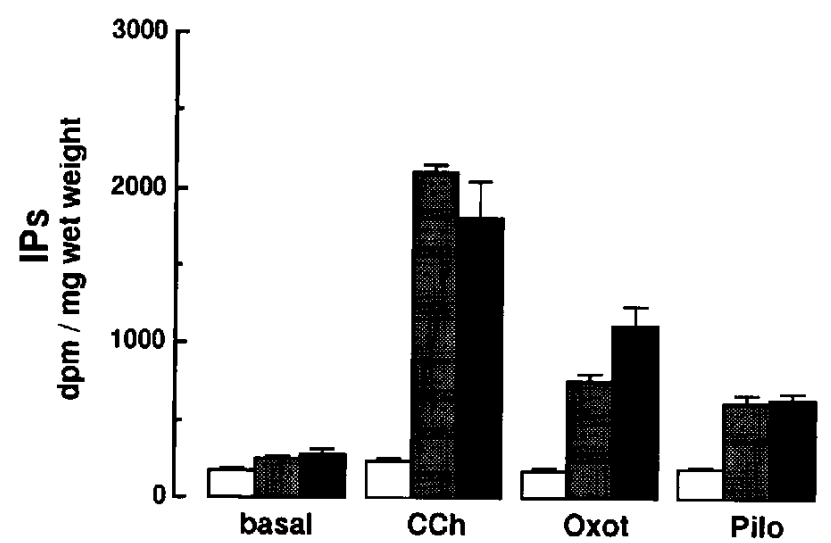

Fig. 6. Effects of extracellular $\mathrm{Ca}^{2+}$ on formations of IPs (inositol phosphates) by muscarinic agonists $(100 \mu \mathrm{M})$ in intact ileal smooth muscle. ${ }^{3} \mathrm{H}$-Labelled ileal smooth muscles were incubated with muscarinic agonists for $10 \mathrm{~min}$ in Li-KRB under $5 \% \mathrm{CO}_{2}-95 \% \mathrm{O}_{2}$ at $37^{\circ} \mathrm{C}$. Values are expressed as radioactivities $(\mathrm{dpm} / \mathrm{mg}$ wet weight) and are the means \pm S.E. for 3 experiments. IPs: $\mathrm{IP}_{1}+\mathrm{IP}_{2}+\mathrm{IP}_{3}$, CCh: carbachol, Oxot: oxotremorine, Pilo: pilocarpine. $\square: \mathrm{Ca}^{2+}$ free (0.5 mM EGTA), $6.5 \mu \mathrm{M} \mathrm{Ca}^{2+}, \square: 1.6 \mathrm{mM} \mathrm{Ca}^{2+}$. 
Effects of $\mathrm{Ca}^{2+}$ on formation of inositol phosphates in intact ileal smooth muscle

Next, we examined the effect of extracellular $\mathrm{Ca}^{2+}$ concentration on the muscarinic agonists-stimulated inositol phosphates (Fig. 6). Inositol phosphate formation stimulated by oxotremorine was reduced $68 \%$ by a lower $\mathrm{Ca}^{2+}$ concentration $(6.5 \mu \mathrm{M})$ compared with that at $1.6 \mathrm{mM}$ $\mathrm{Ca}^{2+}$. However, the level of inositol phosphate formation stimulated by either carbachol or pilocarpine was not significantly different between the lower and higher $\mathrm{Ca}^{21}$ concentrations. Chelating extracellular $\mathrm{Ca}^{2 \dagger}$ with $0.5 \mathrm{mM}$ EGTA in the buffer decreased the inositol phosphates formation stimulated by muscarinic agonists.

\section{DISCUSSION}

Muscarinic agonists have been classified into two groups: full agonists, such as acetylcholine, carbachol and muscarine, and partial agonists, such as oxotremorine, pilocarpine, arecoline and bethanechol. Previously, we demonstrated that the maximum responses of inositol phosphate formation induced by carbachol and oxotremorine in the ileum were different from those in the brain (13). In addition, it is well known that the activation of polyphosphoinositide hydrolysis stimulated by muscarinic agonists was mediated by the G-protein (15). Takayanagi et al. (16) reported that the inhibitory effects of $\mathrm{Gpp}(\mathrm{NH}) \mathrm{p}$ on the affinity of the partial agonists to muscarinic receptors were correlated with their intrinsic activity in contraction. However, direct evidence for the interaction between mACh $\mathrm{R}$ and G-protein in polyphosphoinositide hydrolysis in the ileal smooth muscle has not been provided.

Therefore, the present study showed that G-protein is involved in the inositol polyphosphate formation in ileal smooth muscle. As seen in Fig. 4, in the presence of $\mathrm{Gpp}(\mathrm{NH}) \mathrm{p}$, full agonists, such as acetylcholine and carbachol, potentiated the inositol polyphosphate formation in a synergic manner. On the other hand, partial agonists, such as oxotremorine and pilocarpine, stimulated the formation in an additive manner. These results indicate that full agonists stimulate inositol polyphosphate formation mediated by the G-protein in ileal smooth muscle. The same results were observed in membrane preparations from coronary artery (17), iris sphincter smooth muscle (18) and cardiac muscle (19). In contrast, partial agonists may stimulate partially phosphoinositide hydrolysis in a G-protein-independent manner. Takayanagi et al. (2022) demonstrated that there are two types of propylbenzilylcholine mustard (PrBCM) sensitive- and PrBCMresistant sites of $\mathrm{M} 3 \mathrm{mACh} R$ in ileal smooth muscle. They suggested that the partial agonist pilocarpine caused the contractile response through PrBCM-sensitive sites, and the PrBCM-sensitive sites were not coupled with GTP. These findings suggest that pilocarpine stimulates contraction through muscarinic receptors that are not coupled to G-protein.

In this study, $\mathrm{IP}_{2}$ formation stimulated by carbachol was rapidly and synergistically potentiated by $\mathrm{Gpp}(\mathrm{NH}) \mathrm{p}$ in permeabilized ileal smooth muscle, although carbachol-stimulated $\mathrm{IP}_{3}$ formation was not affected by $\mathrm{Gpp}(\mathrm{NH}) \mathrm{p}$ in the early stage (Fig. 1). It is possible that muscarinic agonist-stimulated G-protein activation induces the two breakdown systems in ileal smooth muscle, phosphatidylinositol monophosphate hydrolysis and phosphatidylinositol bisphosphate hydrolysis. However, further experiments are necessary to examine this possibility.

Several reports demonstrated that muscarinic receptorstimulated inositol phosphates formation is $\mathrm{Ca}^{2+}$-dependent in the ileal smooth muscle $(23,24)$. In the present study, full and partial agonists did not cause inositol phosphates formation in $\mathrm{Ca}^{2+}$-free buffer containing EGTA $(0.5 \mathrm{mM})$ in intact guinea pig ileum (Fig. 6). These findings suggest that muscarinic agonists may activate PLC through $\mathrm{Ca}^{2-}$ influx in the ileal smooth muscle. However, pilocarpine and carbachol could elicit inositol phosphate formation at lower $\mathrm{Ca}^{2+}$ concentration $(6.5 \mu \mathrm{M})$ as well as at higher $\mathrm{Ca}^{2+}$ concentration $(1.6 \mathrm{mM})$. These results suggest the possibility that muscarinic agonists caused phosphoinositide hydrolysis through not only $\mathrm{Ca}^{2+}$ influx but also G-protein activation.

In permeabilized preparations, the formation of inositol phosphates stimulated by carbachol and Gpp(NH)p was also $\mathrm{Ca}^{2+}$-dependent (Fig. 5). The carbacholinduced formation of inositol polyphosphate was potentiated by $\mathrm{Gpp}(\mathrm{NH}) \mathrm{p}$ when the $\mathrm{Ca}^{2+}$ concentration was raised from $0 \mathrm{mM}$ to $0.09 \mathrm{mM} \mathrm{Ca}^{2+}$. This finding suggests that activation of G-protein may increase the $\mathrm{Ca}^{2+}$ sensitivity of PLC activation. Polyphosphoinositide hydrolysis can be elicited even at a very low $\mathrm{Ca}^{2+}$ influx if it is accompanied by G-protein activation.

Several studies have indicated that the activation of PLC is coupled with either PTX-sensitive or -insensitive G-protein (25). In general, inositol phosphate formation stimulated by agonists at the muscarinic receptor seems to be coupled with a PTX-insensitive G-protein $(17,18,26)$. Pretreatment of ileal smooth muscle with PTX and CTX did not affect carbachol-stimulated inositol polyphosphate formation ( $K$. Honda et al., unpublished data).

In conclusion, the present study demonstrated that muscarinic receptor-stimulated polyphosphoinositide hydrolysis in ileal smooth muscle results in inositol polyphosphate formation via G-protein. Moreover, muscarinic receptor-stimulated G-protein activation increases the sensitivity of polyphosphoinositide hydrolysis to $\mathrm{Ca}^{2+}$ in 
ileal smooth muscle. Muscarinic agonists stimulate inositol polyphosphates formation by the interaction of the G-protein activation of a phosphoinositide specific PLC with $\mathrm{Ca}^{2+}$ influx.

\section{Acknowledgments}

This work was supported in part by a Grant-in-Aid from the Ministry of Education, Science and Culture of Japan. We thank Mr. Y. Nakayama, Ms. Y. Nakano, Ms. A. Nakano, Mr. K. Kondo, Mr. M. Ohtuka, Mr. M. Shibata and Mr. T. Makihira for technical assistance. We are grateful to the Chemo-Sero-Therapeutic Research Institute (Kumamoto, Japan) for their generous gifts of pertussis toxin and cholera toxin.

\section{REFERENCES}

1 Nathanson NM: Molecular properties of the muscarinic acetylcholine receptor. Annu Rev Neurosci 10, 195-236 (1987)

2 Peralta EF, Ashkenazi A, Winslow JW, Ramachandra J and Capon DJ: Differential regulation of PI hydrolysis and adenylate cyclase by muscarinic receptor subtypes. Nature 334, $434-437$ (1988)

3 Fukuda K, Kubo T, Akiba I, Maeda A, Mishina M and Numa S: Molecular distinction between muscarinic acetylcholine receptor subtypes. Nature 327, 623-625 (1987)

4 Gil DW and Wolfe BB: Pirenzepine distinguishes between muscarinic receptor-mediated phosphoinositide breakdown and inhibition of adenylate cyclase. J Pharmacol Exp Ther 232, 608-616 (1985)

5 Berrie CP, Birdsall EC, Hulme EC, Keen M and Stockton JM: Solubilization and characterization of guanine nucleotide-sensitive muscarinic agonist binding site from rat myocardium. $\mathrm{Br} \mathrm{J}$ Pharmacol 82, 853-861 (1984)

6 Pfaffinger PJ, Martin JM, Hunter DD, Nathanson NM and Hille B: GTP-binding proteins couple cardiac muscarinic receptors to a $\mathrm{K}$ channel. Nature 317, 536-538 (1985)

7 Martin JM, Hunter DD and Nathanson NM: Islet activating protein inhibits physiological responses evoked by cardiac muscarinic acetylcholine receptors: role of guanosine triphosphate binding proteins in regulation of potassium permeability. Biochemistry 24, 7521-7525 (1985)

8 Martin JM, Subers SW, Halvorsen SW and Nathanson NM: Functional and physical properties of chick artial and ventricular GTP-binding proteins. J Pharmacol Exp Ther 240, 683-688 (1987)

9 Moscona-Amir E, Henis HI and Sokolovsky M: Guanosine 5 -triphosphate binding protein (Gi) and two additional pertussis toxin substrates associated with muscarinic receptors in rat heart myocytes: characterization and age dependency. Biochemistry 27, 4985-4991 (1988)

10 Fisher SK: Inositol lipids and signal transduction at CNS muscarinic receptors. Trends Pharmacol Sci 6, Supp 61-65 (1986)

11 Konno F and Takayanagi I: Relationship between the contractile responses and coupling second messenger systems for muscarinic drugs in the guinea pig ileal longitudinal muscle. Arch Int Pharmacodyn Ther 301, 15-19 (1989)

12 Wang XB, Osugi $\mathrm{T}$ and Uchida S: Different pathways for $\mathrm{Ca}^{2+}$ influx and intracellular release $\mathrm{Ca}^{2+}$ mediated by muscarinic receptors in ileal longitudinal smooth muscle. Jpn J Pharmacol 58, 407-415 (1992)

13 Honda K, Takano $\mathrm{Y}$ and Kamiya H: Pharmacological profiles of muscarinic receptors in the longitudinal smooth muscle of guinea pig. Jpn J Pharmacol 62, $43-47$ (1993)

14 Berridge MJ, Dawson CP, Downes CP, Heslop JP and Irvine $\mathrm{R}$ : Change in the levels of inositol phosphates after agonist-dependent hydrolysis of membrane phosphoinositide. Biochem J 212, 473-482 (1983)

15 Birnbaumer L, Abramowitz J and Brown M: Receptor-effector coupling by $\mathrm{G}$ proteins. Biochem Biophys Acta 1031, 163-224 (1990)

16 Takayanagi I, Koike $\mathrm{K}$ and Okumura K: Intrinsic activity and effects of guanyl-5'-yl imidodiphosphate, Gpp( $\mathrm{NH}) \mathrm{p}$ on the affinity of partial agonists to the muscarinic receptor. Eur J Pharmacol 99, 107-110 (1984)

17 Sasaguri $T$, Hirata $M$, Itoh $T$, Koga $T$ and Kuriyama $H$ : Guanine nucleotide binding protein involved in muscarinic responses in the pig coronary artery is insensitive to islet-activating protein. Biochem J 239, 567-574 (1986)

18 Honkanen RE and Abdel-Latiff AA: Muscarinic-agonist and guanine nucleotide stimulation of myo-inositol trisphosphate formation in membranes isolated from bovine iris sphincter smooth muscle: Effects of short-term cholinergic desensitization. Membr Biochem 8, 39-59 (1989)

19 Jones LG, Goldstein D and Brown JH: Guanine nucleotidedependent inositol trisphosphate formation in chick heart cells. Circ Res 62, 299-305 (1988)

20 Harada $M$, Koike $\mathrm{K}$ and Takayanagi I: Characterization of subtype of propylbenzilcholine mustard (PrBCM)-sensitive and -resistant muscarinic cholinoceptors in guinea pig ileal muscle. Jpn J Pharmacol 59, 485-487 (1992)

21 Takayanagi I, Harada $\mathbf{M}$ and Koike $\mathrm{K}$ : A difference in receptor mechanisms for muscarinic full and partial agonist. Jpn J Pharmacol 56, 23-31 (1991)

22 Kiuchi Y, Kumagai N, Hisayama T and Takayanagi I: Guanosine 5 -triphosphate converts some populations of propylbenzilylcholine mustard-sensitive muscarinic cholinoceptor sites to sites resistant to the drug in intestinal smooth muscle. Jpn J Pharmacol 55, 329-338 (1991)

23 Best L, Brooks KJ and Bolton TM: Relationship between stimulated inositol lipid hydrolysis and contractility in guinea pig visceral longituginal smooth muscle. Biochem Pharmacol 34, 2297-2301 (1986)

24 Watson SP, Lai $\mathbf{J}$ and Sasaguri $\mathrm{T}: \mathrm{K}^{+}$-stimulation of the phosphoinositide pathway in guinea-pig ileum longitudinal smooth muscie is predominantly neuronal in origine and mediated by the entry of extracellular $\mathrm{Ca}^{2+}$, Br J Pharmacol 99, 212-216 (1990)

25 Cockcroft $\mathrm{S}$ and Thomas GMH: Inositol-lipid-specific phospholipase $C$ isoenzymes and their differential regulation by receptors. Biochem J 288, 1-14 (1992)

26 Master SB, Martin MW, Harden TK and Brown JH: Pertussis toxin does not inhibit muscarinic-receptor-mediated phosphoinositide hydrolysis or calcium mobilization. Biochem J 227, 933-937 (1985) 